\title{
Prognostic Effect of Symptomatic and Asymptomatic Venous Thromboembolism in Patients with Gastric Cancer
}

\author{
Yakup BOZKAYA ${ }^{1}$, Nuriye OZDEMIR ${ }^{1}$, N. Serkan DEMIRCI ${ }^{1}$, Gökmen U. ERDEM ${ }^{1}$, \\ Ozan YAZICI ${ }^{1}$, Süheyla ARSLAN ${ }^{2}$, Nurullah ZENGIN ${ }^{1}$ \\ ${ }^{1}$ Ankara Numune Research and Training Hospital, Department of Medical Oncology \\ ${ }^{2}$ Yıldırım Beyazit University Faculty of Medicine, Department of Radiation Oncology, Ankara, TURKEY
}

\begin{abstract}
The purpose of this study is to assess the incidence of symptomatic and asymptomatic venous thromboembolism (VTE) and their prognostic effect on survival in patients with gastric cancer. A total of 201 VTE cases from 1420 eligible patients with gastric cancer were enrolled in this study. VTE events were divided into two groups as symptomatic or asymptomatic according to the symptomatology of thrombosis. Trombus Overall Survival (TOS) was defined as the period between the date of VTE diagnosis and the date of death or the date of last visit of patient. Of these 201 VTE cases, 101 were symptomatic. Metastatic period (61.7\%) and the first 6 months (67.7\%) after the cancer diagnosis were associated with the highest incidence of VTE. Extremity (97.7\%), port-related (100\%) and pulmonary (59.7\%) thrombosis were found to be clinically symptomatic, while visceral thrombosis (97.3\%) were mostly asymptomatic. TOS for stage I-III patients with symptomatic VTE was found to be 26.4 months in comparison to 33.2 months for those with asymptomatic VTE $(p=0.29)$. TOS for symptomatic and asymptomatic groups with metastatic disease were 3.4 months and 6 months, respectively $(p=0.01)$. In multivariate analysis of metastatic patients, symptomatic thrombosis was statistically significant factor for poor TOS. In conslusion, metastatic stage and first 6 months after cancer diagnosis are the crucial periods in which the thrombosis mostly occurs. Although symptomatic thrombosis in patients with metastatic gastric cancer had an adverse prognostic effect, asymptomatic VTE had no significant impact on the prognosis, hence asymptomatic VTE may be followed without anticoagulant therapy.
\end{abstract}

Keywords: Anticoagulant therapy, Asymptomatic venous thromboembolism, Gastric cancer, Symptomatic venous thromboembolism, Thrombosis

\section{ÖZET}

\section{Mide Kanserli Hastalarda Semptomatik ve Asemptomatik Venöz Tromboembolizmin Prognostik Etkisi}

Bu çalışmanın amacı mide kanserli hastalarda semptomatik ve asemptomatik venöz tromboembolizmin (VTE) insindansını ve onların sağkalım üzerine prognostik etkisini değerlendirmektir. Mide kanseri tanısı alan 1420 hastadan toplam 201 VTE saptanan hasta çalışmaya alındı. VTE ile ilgili semptom durumuna göre semtomatik ve asemptomatik olmak üzere iki gruba ayrıldı. Tromboz genel sağkalım (TGS), VTE tanı tarihinden ölüm veya son kontrol tarihine kadar geçen süre olarak kabul edildi. Toplam VTE'li 201 hastanın 101 'i semptomatikdi. Metastatik evre (61.7\%) ve kanser tanısından sonraki ilk 6 ay (67.7\%) VTE insidansının en yüksek olduğu dönemdi. Ekstremite (97.7\%), pulmoner (59.7\%) ve port-ilişkili (100\%) tromboz klinik olarak çoğunlukla semptomatik iken, visseral trombozlar (97.3\%) çoğunlukla asemptomatik idi. Semptomatik VTE'li evre I-III hastalar için TGS 26.4 ay iken asemptomatik VTE’li hastalar için 33.2 ay olarak bulundu ( $p=0.29$ ). Metastatik evre (evre IV) semptomatik ve asemptomatik gruplar için TGS sırasıyla 3.4 ay ve 6 ay olarak bulundu ( $p=0.01$ ). Metastatik evre semptomatik ve asemptomatik VTE li hastaların çok değişkenli analizinde semptomatik tromboz sağkalım için bağımsız kötü prognostik faktör olarak bulundu. Sonuç olarak, metastatik evre ve kanser tanısından sonraki illk 6 ay tromboz için en kritik dönemdir. Metastatik mide kanserli hastalarda semptomatik tromboz sağkalım üzerine kötü prognostik etkiye sahip iken, asemptomatik trombozun önemli bir etkisi yoktur. Bu nedenle asemptomatik VTE'li hastalar antikoagülan tedavi verilmeksizin takip edilebilir.

Anahtar Kelimler: Antikoagülan tedavi, Asemptomatik venöz tromboembolizm, Mide kanseri, Semptomatik venöz tromboembolizm, Tromboz 


\section{INTRODUCTION}

Venous thromboembolism (VTE) occurred in patients with cancer is a major cause of mortality and morbidity. As compared with the general population, thromboembolic risk is 4 to 6 times higher in cancer patients. ${ }^{1,2}$ This increased tendency to thrombosis in these patients is associated with procoagulant effect of tissue factor expressed through tumor cells, overexpression of membrane adhesion molecules and decreased rate of fibrinolysis. ${ }^{3-5} \mathrm{Be}-$ sides, other major risk factors contributing to VTE in cancer patients include surgery, immobilization, hospitalization, erythropoietic/granulopoietic agents, chemotherapy administration (a 2 - to 6 fold increased risk in comparison to the general population) and central venous catheterization. ${ }^{6-9}$

While the incidence of thromboembolism varies depending on the type of cancer disease, the highest incidence in compliance with the large epidemiological studies has been reported to be in ovarian, brain or pancreatic cancer. ${ }^{10,11}$ In a study designed by Chew et al who investigated the incidence of VTE among the most common 12 cancer types, patients with metastatic pancreatic cancer were found to be at the highest risk for VTE with a frequency of 20 events per 100 patient-years followed by patients with metastatic gastric cancer who were the second most high-risk group for VTE with an incidence of 10.7 events per 100 patient-years. ${ }^{12}$ In another study, Tetzlaff et al evaluated the frequency of VTE only in the patients with metastatic gastric cancer receiving chemotherapy treatment. ${ }^{13}$ Although the risk of thrombosis in patients with gastric cancer has been documented to be at such high rates, previous studies were limited with a small sample size and generally did not include all groups of patients with gastric cancer. ${ }^{14}$

The initiation of extensive use of Multi-detector computed tomography in cancer patients has led to an increase in detecting of asymptomatic VTE. While anticoagulant therapy is a standard approach in the treatment of symptomatic thrombosis, it is not yet clear whether to treat asymptomatic thrombosis. Specifically, although there are available data suggesting that symptomatic thrombosis may be associated with a poor prognosis, prognostic significance of asymptomatic thrombosis has still remained uncertain. Our aim in this present study is to compare the clinicopathological features and survival data of asymptomatic and symptomatic thrombosis and also to perform a subgroup analysis of these thrombosis according to the occurrence localisation in our patients with gastric cancer developing VTE during follow up.

\section{PATIENTS AND METHODS}

Medical records of 1420 patients with histologically proven gastric cancer diagnosed between 2002 and 2015 in our hospital were retrospectively analyzed. In order to detect the venous thromboembolism occurred in any part of the body within the first two years following gastric cancer diagnosis; imaging reports of the patients performed by radiology or nuclear medicine department [Doppler ultrasonography, computed tomography (CT), CT - angiography, conventional angiography and ventilation / perfusion scintigraphy] were examined. The cases of VTE were categorised into 4 groups as visceral, pulmonary, extremity and port-related thrombosis according to the occurrence localisation. The definition of "visceral thrombosis" was used to define the thrombosis occurred in any visceral organ (except brain) or in any large vessels such as vena cava (including thrombosis of the iliac region) and the description of "pulmonary thrombosis" was used to define the pulmonary thromboembolism. The thrombosis occurred in lower (including the femoral vein) or upper extremities was classified as extremity thrombosis. The thrombosis associated with central venous catheter applied for chemotherapy administration was defined as port - related thrombosis. VTE events were divided into two groups as symptomatic or asymptomatic according to the symptomatology of thrombosis. Patients whose thrombosis were radiologically confirmed after a clinical suspicionof VTE were accepted symptomatic. On the other hand, patients who were incidentally radiologically diagnosed with a VTE during routine cancer screening but had no symptoms related to thrombosis were accepted as asymptomatic. Patients with arterial and superficial vein thrombosis or phlebitis were excluded from the study. Additionally, presence of pregnancy, patients using drugs with known procoagulant side 
effect, patients with secondary primary tumor and under 18 years of age were the other exclusion criteria of the study.

For the purpose of assessing the comorbidity conditions, the presence of previous medical history including myocardial infarction, congestive heart failure, peripheral vascular disease, cerebrovascular disease, chronic lung disease, connective tissue disease, diabetes mellitus, hypertension, hyperlipidemia, chronic kidney and liver disease (cirrhosis or chronic hepatitis) was investigated. The Eastern Cooperative Oncology Group (ECOG) scale of performance status was considered as the performance condition of the patients during the diagnosis of thrombosis. Final status of the patients was determined by checking both the patients' medical records and Turkish Identification Number from the records of Central Population Management System (Türkiye Cumhuriyeti Merkezî Nüfus İdare Sistemi).

\section{Statistical Analysis}

The computer program 'Statistical Package for The Social Sciences' for Windows (SPSS; version 18.0, IBM, Chicago, IL, USA) was used for statistical analyses, and a p-value $<0.05$ was considered statistically significant. The variables were investigated according to visual (histograms and probability plots) and analytical methods (Kolmogorov-Smirnov/Shapiro-Wilk tests) to determine whether they were normally distributed. Nonparametric variables are presented as the median and range. Categorical variables were analyzed using Chi squared or Fisher exact tests. Survival analysis was performed according to the Kaplan-Meier Method and log-rank statistics were used to compare the subgroups. The possible factors identified with univariate analyses were further entered into the Cox regression analysis with backward selection to determine independent predictors of survival. The time of VTE was calculated as the time from the diagnosis of gastric cancer until the diagnosis of VTE. Trombus Overall Survival (TOS) was defined as the period between the date of VTE diagnosis and the date of death or the date of last visit of patient.

\section{RESULTS}

\section{Patient Characteristics}

Over a 13-year period, a total of 201 VTE cases were identified. Clinicopathological characteristics of the patients are shown in Table 1. Median age of the patients with VTE was 62 years (range: 27-87) and $74.6 \%(n=150)$ of these patients were male. Diffuse type (Lauren classification) was found to be the most common (57.2\%) histological tumor type. Although there was not a significant difference in terms of the localisation rates of the primary tumor, antrum localisation was more likely to be associated with VTE events, comprising $37.8 \%$ of all cases. About $43.3 \%$ of patients had an comorbidity, accompanying mostly essential hypertension and diabetes mellitus. ECOG performance score in $56.7 \%$ of patients was 0 or 1 at the time of VTE diagnosis. Approximately $62.7 \%$ of patients had undergone curative or palliative surgical intervention prior to diagnosis of thrombosis. The proportion of patients receiving adjuvant chemotherapy and chemoradiotherapy was $43.3 \%$ and $37.8 \%$, respectively. The most frequent metastasis sites during the development of a thrombotic event were liver $(29.9 \%)$ and distant intra abdominal lymph nodes $(28.4 \%)$.

\section{The Incidence of VTE}

Venous thromboembolism was detected in $14.1 \%$ $(n=201)$ of whole patients with gastric cancer. When considering the VTE events according to the localisation, the rates of visceral, pulmonary, extremity and port - related thrombosis were $36.8 \%$, $33.3 \%, 21.9 \%, 8 \%$, respectively, indicating a highest rate for visceral thrombosis. The rates of stage I, II, III, IV disease of the patients according to the frequency of VTE diagnosis were $3 \%, 14.4 \%$, $20.9 \%$ and $61.7 \%$, respectively, demonstrating a greater VTE incidence in metastatic patients. The incidence of VTE was the most frequent (with a rate of $67.7 \%$ ) within the first 6 months after gastric cancer diagnosis. VTE in $18.9 \%$ of the patients was detected at the time of diagnosis of gastric cancer, however, in $46.3 \%$ of the patients, it was diagnosed during chemotherapy treatment. 
International Journal of Hematology and Oncology

Table 1. Characteristics of Patients with symptomatic and asymptomatic venous thromboembolism

\section{Characteristics}

Age (median, range)

Gender

Female

Male

Smoking History

ECOG

2-4

0.22

Lauren Classification

Intestinal type

Diffuse type

Unknown

Localisation

Fundus/Cardia/Diffuse $\quad 67$ (33.3)

Corpus $\quad 58(28.9)$

Antrum

Comorbidity

Yes $\quad 87(43.3)$

No

TNM Stage

$1 \quad 6(4.5)$

$2 \quad 29(14.4)$

$3 \quad 42(20.9)$

$4 \quad 124(61.7)$

Port catheter

Yes 158 (78.6)

No $43(21.4)$

Hemoglobine (during thrombosis)

$\leq 10 \quad 56(27.9)$

Albumin (during thrombosis)

$>35 \quad 75$ (37.3)

$\leq 35 \quad 126(62.7)$

Surgery

Yes $126(62.7)$

No

Adjuvant therapy

Chemotherapy 87 (43.3)

Chemoradiotherapy

Chemotherapy

5 - Fluorouracil $\quad 131$ (65.2)

Cisplatin 111 (55.2)

Docetaxel 68 (33.8)

Oxaliplatin

Type of thrombosis

Visceral

$12(6)$

Pulmonary

Extremity

Port-related

Time of VTE

First 6 months $\quad 136(67.7)$

Second 6 months $\quad 35(17.4)$

Between 1th and 2nd years 30 (14.9)

Site of metastasis during thrombosis

Liver 60 (29.9)

Periton 24 (11.9)

Distant intraabdominal 57 (28.4) lymph nodes

Lung

$21(10.4)$
Symptomatic (\%) n= 101

$60(27-85)$

$34(33.7)$

67 (66.3)

$41(40.6)$

53 (52.5)

48 (47.5)

32 (31.7)

58 (57.4)

11 (10.9)

34 (33.7)

27 (26.7)

40 (39.6)

43 (42.6)

58 (57.4)

2.0 (2)

14 (13.8)

23 (22.8)

62 (61.4)

85 (84.2)

16 (15.8)

28 (27.7)

73 (72.3)

34 (33.7)

67 (66.3)

62 (61.4)

39 (38.6)

48 (47.5)

44 (43.6)

72 (71.3)

61 (60.4)

37 (36.6)

$8(7.9)$

2.0 (2)

40 (39.6)

43 (42.6)

16 (15.8)

66 (65.3)

17 (16.8)

18 (18)

27 (26.7)

14 (13.9)

31 (30.7)

$9(8.9)$
Asymptomatic (\%) n= 100

$63(33-87)$

0.01

$17(17)$

$83(83)$

$60(60)$

0.007

0.006

61 (61)

39 (39)

31 (31)

57 (57)

$12(12)$

33 (33)

31 (31)

$36(36)$

45 (45)

55 (55)

4.0 (4)

15 (15)

19 (19)

62 (65)

73 (73)

27 (27)

0.05

28 (28)

72 (72)

0.96

41(41)

59(59)

64 (64)

36 (36)

0.70

39 (39)

32 (32)

0.22

59 (59)

50 (50)

31 (31)

4 (4)

0.09

72 (72)

27 (27)

$1.0(1)$

$<0.0001$

70 (70)

$18(17.9)$

12 (12)

0.51

33 (33)

$10(10)$

26 (26)

0.33

0.39

0.46

12 (12)

0.47

$\mathrm{ECOG}=$ Eastern Cooperative Oncology Group; VTE= Venous thromboembolism; TNM= Tumor Node Metastasis 
Table 2. The treatments of VTE

\begin{tabular}{|llll|}
\hline Characteristics & $\begin{array}{l}\text { Symptomatic VTE (\%) } \\
\mathbf{n = 1 0 1}\end{array}$ & $\begin{array}{l}\text { Asymptomatic VTE (\%) } \\
\mathbf{n = 1 0 0}\end{array}$ & $\begin{array}{l}\text { Total } \\
\mathbf{n = 2 0 1}\end{array}$ \\
\hline Anticoagulant Therapy & & & $95(47.3)$ \\
LMWH & $92(91.1)$ & $3.0(3)$ & $6.0(3)$ \\
Warfarin sodium & $5.0(4.9)$ & $1.0(1)$ & $3.0(1.5)$ \\
Acetylsalicylic acid & $1.0(1)$ & $2.0(2)$ & $97(48.2)$ \\
No treatment & $3.0(3)$ & $94(94)$ & \\
\hline LMWH, Low molecular weight heparin; VTE, Venous thromboembolism & & \\
\end{tabular}

\section{Symptomatic and Asymptomatic Thrombosis}

Of these 201 VTE cases, 101 were symptomatic and 100 were asymptomatic. Although both groups had a male dominance, number of woman patients were significantly higher among patients with symptomatic VTE in comparison to patients with asymptomatic VTE $(p=0.007)$. When considering the symptomatology according to the occurrence sites of thrombosis, extremity $(97.7 \%)$, port-related $(100 \%)$ and pulmonary $(59.7 \%)$ thrombosis were found to be clinically symptomatic, while visceral thrombosis (97.3\%) were mostly asymptomatic. Cases of visceral thrombosis were generally detected incidentally during an imaging procedure performed for routine tumor evaluation. The most frequently used chemotherapeutic agents in patients prior to the diagnosis of thrombosis were 5-fluorouracil (65.2\%) and cisplatin (55.2\%). Symptomatic and asymptomatic thrombosis most commonly occurred $(65.3 \%$ and $70 \%$, respectively) within the first 6 months and vast majority of thrombosis in each group was more frequent in metastatic period (61.4\% and $62 \%$, respectively).

Almost all of the patients with symptomatic VTE $(97 \%, \mathrm{n}=98)$ received anticoagulant therapy with a median duration of 6 months (range: 1-24 months). As anticoagulant therapy; the number of patients in symptomatic group treated with low molecular weight heparin (LMWH), warfarin sodium and acetylsalicylic was 92, 5 and 1, respectively. By contrast, only $6(6 \%)$ patients in asymptomatic group received anticoagulant therapy (Table 2).

\section{Survival Analysis}

The prognostic impact of symptomatic and asymptomatic VTE on TOS was assessed. Patients with symptomatic VTE had a 8.8 months of TOS compared to 15.7 months for those with asymptomatic VTE (95\% CI, 5.3-12.3 vs 95\% CI, 11.9-19.5, respectively, $\mathrm{p}=0.07$ ) (Figure 1). When analyzing the survival of the patients according to the stage I-III (non-metastatic) or stage IV (metastatic) disease, TOS for stage I-III patients with symptomatic VTE was found to be 26.4 months in comparison to 33.2 months for those with asymptomatic VTE ( 95\% CI, 9.0-43.8 vs 95\% CI, 26.0-40.5, respectively, $\mathrm{p}=0.29$ ) (Figure 2). TOS for symptomatic and asymptomatic groups with Stage IV disease were 3.4 months and 6 months, respectively $(95 \%$ CI, $1.8-5.0$ vs $95 \% \mathrm{CI}, 4.5-7.5$, respectively, $\mathrm{p}=$ 0.01 ) (Figure 3). Furthermore, OS durations (from the time of metastasis until the death or last visit) for stage IV patients with symptomatic and asymptomatic VTE were 7.6 months and 10.4 months, respectively (95\% CI, 5.5-9.7 vs 95\% CI, 4.9-15.9, respectively, $\mathrm{p}=0.02$ ).

In univariate analysis of stage IV patients, ECOG performance score of $\geq 2$, albumin of $\leq 35 \mathrm{mg}$ / dL, extremity/pulmonary and symptomatic thrombosis appeared to have an association with poorer survival rates. However, multivariate analysis showed that he ECOG performance score of $\geq 2$, albumin of $\leq 35 \mathrm{mg} / \mathrm{dL}$ and symptomatic thrombosis were statistically significant factors (Table 3 ). 


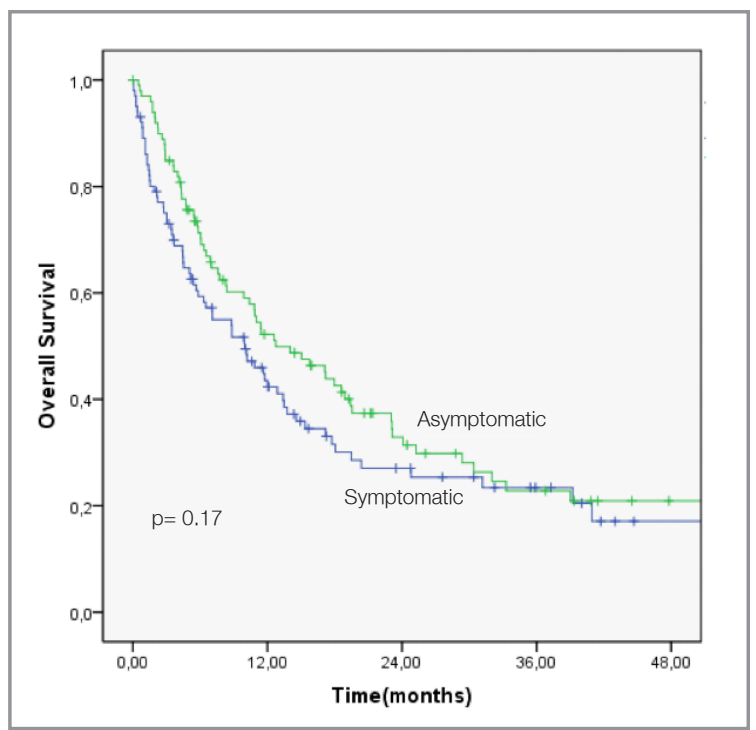

Figure 1. Kaplan Meier survival curves of patients with symptomatic and asymptomatic VTE.

\section{DISCUSSION}

To our knowledge, our study is one of the most comprehensive trials focused on VTE occurring in patients with gastric cancer. Incidence of VTE in our patients diagnosed with gastric cancer was found to be $14.1 \%$. In a study performed by Lee et al that is also one of the two largest studies designed in Asian population, the frequency of VTE (symptomatic or asymptomatic) was reported to be $3.5 \%$ among a total of 2085 patients with gastric cancer ${ }^{14}$ In the other Asian study conducted by Kang et al,

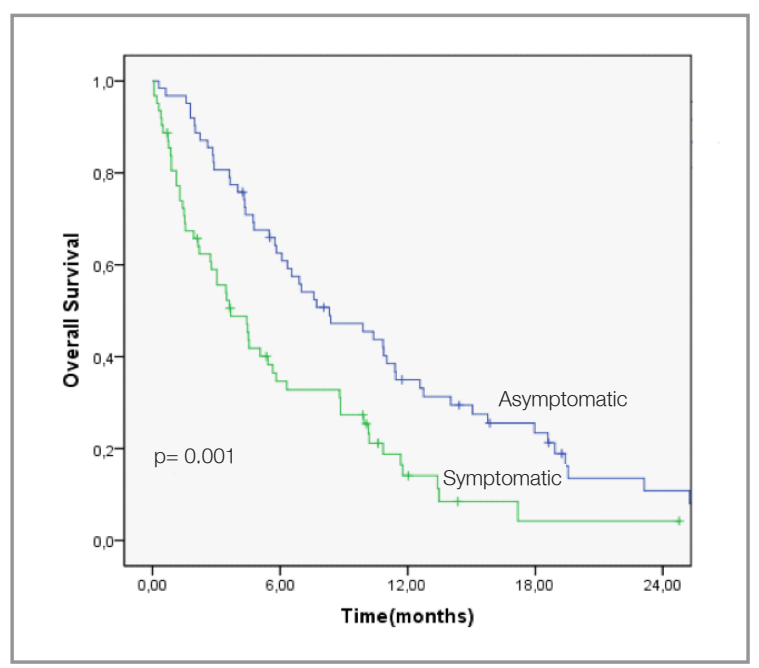

Figure 3. Kaplan Meier survival curves of the stage IV patients with symptomatic and asymptomatic VTE group.

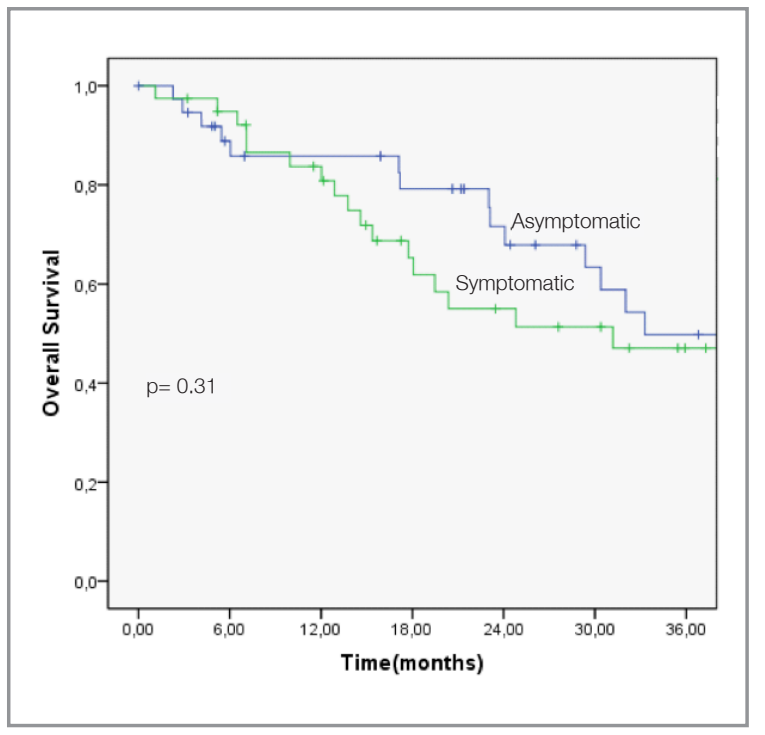

Figure 2. Kaplan Meier survival curves of the stage I-III patients with symptomatic and asymptomatic VTE group.

VTE (symptomatic or asymptomatic) incidence was observed to be $3.3 \%$ in 3095 patients with advanced gastric cancer. ${ }^{15}$ Tetzlaff et al investigated the incidence of arterial and venous thrombosis during or before chemotherapy treatment in American population with advanced gastroesophageal carcinoma and reported the VTE (symptomatic or asymptomatic) incidence to be $13.6 \% .^{13}$ One another study investigating the incidence of arterial and venous thrombosis according to the given chemotherapeutic agents reported the incidence of thrombosis to be between $2.2 \%-12.1 \%$ in patients with advanced gastroesophageal carcinoma. ${ }^{16}$ Due to the differences in study populations mentioned above, it is difficult to directly compare our results with the current literature. However, we found a higher rate of VTE in our study compared to those reported in the Asian and American studies. Besides, the fact that we included 15 cases of port - related thrombosis in our study may partly play a role in the high rate of our result, but race and ethnicity may also have an important role in these differences. Because, mutations that are highly important risk factors for thrombosis may show ethnic and geographical variations. For instance, frequency of factor V Leiden gene mutation that is the most common thrombophilic mutation in literature was reported to be 3-5\% in Europe and 7.1-10.3\% in Turkey, while not reported in Chinese, Japanese 


\begin{tabular}{|c|c|c|c|c|}
\hline Characteristics & $\mathbf{N}(\%)$ & $\begin{array}{l}\text { Univariate ana- } \\
\text { lysis for OS }\end{array}$ & $P$ value & Multivariate analysis \\
\hline \multicolumn{5}{|l|}{ Age (mean, years) } \\
\hline$\leq 60$ & $60(48.4)$ & 4.7 & 0.52 & \\
\hline$>60$ & $64(51.6)$ & 4.4 & & \\
\hline \multicolumn{5}{|l|}{ Gender } \\
\hline Female & $31(25.0)$ & 3.6 & 0.19 & \\
\hline Male & $93(75.0)$ & 5.4 & & \\
\hline \multicolumn{5}{|l|}{ ECOG score } \\
\hline $0-1$ & $50(40.3)$ & 8.8 & 0.001 & $\mathrm{p}=0.01, \mathrm{HR}: 1.661, \% 95 \mathrm{Cl}: 1.112-2.483$ \\
\hline $2-4$ & $74(59.7)$ & 3.4 & & \\
\hline \multicolumn{5}{|l|}{ Comorbidity } \\
\hline Yes & $49(39.5)$ & 4.0 & 0.21 & \\
\hline No & $75(60.5)$ & 5.4 & 0.21 & \\
\hline \multicolumn{5}{|l|}{ Lauren Classification } \\
\hline Intestinal type & $29(27.9)$ & 6.7 & 0.17 & \\
\hline Diffuse type & $75(72.1)$ & 4.1 & & \\
\hline \multicolumn{5}{|l|}{ Hemoglobin (gr/dL) } \\
\hline$\leq 10$ & $39(31.5)$ & 3.4 & 0.34 & \\
\hline$>10$ & $85(68.5)$ & 5.5 & & \\
\hline \multicolumn{5}{|l|}{ Albumin (mg/ dL) } \\
\hline$>35$ & $33(26.6)$ & 13.4 & 0.006 & $\mathrm{p}=0.02, \mathrm{HR}: 1.670, \% 95 \mathrm{Cl}: 1.078-2.588$ \\
\hline$\leq 35$ & $91(73.4)$ & 3.6 & & \\
\hline \multicolumn{5}{|l|}{ Thrombosis (during CT) } \\
\hline Yes & $57(46.0)$ & 5.4 & 0.54 & \\
\hline No & $67(54.0)$ & 4.3 & & \\
\hline \multicolumn{5}{|l|}{ Time of VTE } \\
\hline First 6 months & $87(70.2)$ & 4.3 & 0.42 & \\
\hline Between 6 and 24 months & $37(29.8)$ & 6.3 & & \\
\hline \multicolumn{5}{|l|}{ Number of metastasis } \\
\hline 1 & $61(49.2)$ & 6.0 & 0.34 & \\
\hline$\geq 2$ & $63(50.8)$ & 4.3 & & \\
\hline \multicolumn{5}{|c|}{ Thrombosis at gastric cancer presentation } \\
\hline Yes & $29(23.4)$ & 4.3 & 0.88 & \\
\hline No & $95(76.6)$ & 5.4 & & \\
\hline \multicolumn{5}{|l|}{ Site of thrombosis } \\
\hline Extremity / Pulmonary & $69(55.6)$ & 3.4 & 0.006 & $p=0.14$, HR:1.371, \%95 Cl: 0.896- 2.098 \\
\hline Visceral / port-related & $55(44.4)$ & 6.9 & & \\
\hline \multicolumn{5}{|l|}{ Symptomatic/Asymptomatic } \\
\hline Symptomatic & $62(50.0)$ & 3.4 & 0.01 & $p=0.01$, HR: $1.601, \% 95 \mathrm{Cl}: 1.098-2.335$ \\
\hline Asymptomatic & $62(50.0)$ & 6.0 & & \\
\hline
\end{tabular}

and African population. ${ }^{17,18}$ Additionally, since the thrombotic events in cancer patients mostly occur in advanced disease, the fact that patients with gastric cancer are generally diagnosed in earlier stages of disease in Asian populations through widespread screening programs for gastric cancer may contribute to a less incidence of thrombosis in Asian population.

VTE is more frequent within the first 6 months following a cancer diagnosis and mostly occurs in advanced stages of malignancies. Similarly, in a

large study performed by Chew et al involving the most common 12 cancer types, advanced stages of disease and the first 6 months after the diagnosis of cancer were reported to be associated with the highest incidence of VTE. ${ }^{12}$ Likewise Lee et al detected the $65 \%$ of total 73 VTE cases in advanced stages of disease or within the first 6 months after gastric cancer diagnosis. ${ }^{14}$ As with the literature, $62 \%$ of VTE cases in our study were detected in patients with advanced disease. In addition to that, $68 \%$ of our patients with VTE were diagnosed 
within the first 6 months following gastric cancer diagnosis, however, VTE continued to occur with a descending frequency despite the the progression of disease in the subsequent periods. The common causes of thrombosis particularly observed in this period may be associated with some predisposing factors such as surgery, chemoradiotherapy and hospitalization along with the aggressive biological behaviour of cancer disease, leading to procoagulant activation.

As well as its symptomatic clinical aspect, thrombosis in patients with gastric cancer may also be asymptomatic and it is diagnosed incidentally during a radiological imaging procedure. ${ }^{19}$ Thus, the actual data regarding the prevalence of asymptomatic thrombosis in gastric cancer is still unclear. Visceral thrombosis mostly develops on the basis of chronic inflammatory diseases, chronic myeloproliferative disorders, liver cirrhosis, various intra abdominal tumors and some hereditary diseases andusually represents as an asymptomatic thrombosis with rare clinical manifestations. ${ }^{20-23}$ By contrast, extremity, port - related and pulmonary thrombosis usually appear to be clinically symptomatic. Cronin et al determined the incidence of asymptomatic pulmonary VTE to be $31 \%$ in a study investigating the prevalence of asymptomatic thrombosis in patients with hematologic and solid tumors. ${ }^{24}$ Singh et al reported the incidence of asymptomatic pulmonary thrombosis to be as $23 \%$ among patients with gastrointestinal tract cancers. ${ }^{25}$ However, half of the patients with VTE in our study were asymptomatic. Specifically, while pulmonary, port - related and extremity thrombosis in our population were generally symptomatic, visceral thrombosis were observed to be asymptomatic. In addition to this, our incidence of pulmonary thrombosis in small veins among patients with asymptomatic thrombosis was $27 \%$ indicating a similar rate to the results of previous studies. ${ }^{24,25}$ Visceral thrombosis was the most common type of VTE in our study and was usually detected incidentally during an imaging procedure performed for routine tumor assessment. Therefore, the incidence of visceral thrombosis generally depends on the frequency of imaging studies and this condition should be considered in case of studies associated with cancer disease.
The treatment strategy of VTE for cancer patients is nearly similar to those for non-cancer patients. The main purpose of this treatment is to reduce the risk of embolism and thrombus expansion an also to lower the risk of recurrence, while providing a minimal bleeding risk. For this purpose, LMWH is more preferred over warfarin because of having less bleeding risk and lower rates of drug interactions compared to warfarin. ${ }^{26,27}$ In our study, $97 \%$ of patients with symptomatic VTE were administered anticoagulant therapy for a median duration of 6 months, while $94 \%$ of asymptomatic counterparts did not receive any anticoagulant therapy.

Despite all the available current treatment approaches, median OS for patients with metastatic gastric cancer is approximately 1 year. ${ }^{28,29}$ Although metastatic patients with asymptomatic VTE in our study did not receive any anticoagulant therapy, OS was found to be similar to the expected survival durations (10.4 months). This finding therefore may suggest the opinion of that metastatic gastric cancer patients with asymptomatic VTE who were not given any anticoagulant therapy could have no negative impact on their prognosis.

There are several studies in relation to prognostic effects of asymptomatic and symptomatic thrombosis in patients with pancreas, ovary and prostat cancer, indicating a poor prognosis for both symptomatic and asymptomatic VTE..$^{19,30,31}$ Khorana et al have considered the gastric cancer to be as the most thrombosis prone tumor along with pancreatic cancer. ${ }^{32}$ Despite the increased tendency to thrombosis, small number of studies regarding the thrombosis in gastric cancer are available, however, prognostic effect of asymptomatic and symptomatic thrombosis in these studies has remained unclear. When considering the all group of patients in our study, neither asymptomatic nor symptomatic thrombosis had any significant prognostic superiority over each other. However, in subset analysis of the groups according to stages as non-metastatic (stages I-III) or metastatic disease (stage IV), the univariate and multivariate analysis showed that metastatic patients with symptomatic thrombosis appeared to have a significant adverse prognosis with a median survival of 3.4 months following the diagnosis of thrombosis (6 months in asymptomatic VTE). This therefore suggests that symptomatic 
thrombosis in patients with metastatic gastric cancer may have a poor prognosis.

In our study, extremity and pulmonary thrombosis in patients with metastatic stage were found to be associated with a statistically significant poor survival compared to visceral and port-related thrombosis. This finding was consistent with the previous study of Lee et al who also reported an poor survival for extremity and pulmonary thrombosis in comparison to visceral thrombosis. ${ }^{14}$ Thus, if observed, a more aggressive treatment should be considered in cases of extremity and pulmonary thrombosis in metastatic patients.

Aside from its retrospective and single center nature, the most important limitation of our study was that various of non-specific symptoms related to thrombosis in our patients may be omitted as a general tumor symptoms and may be mistakenly accepted as asymptomatic VTE cases. Another limitation was that diagnosis of thrombosis was made with different diagnostic tools. In addition, the presence of patients with synchronous symptomatic and asymptomatic thrombosis in the symptomatic group might have caused some cases of asymptomatic thrombosis to be missed.

In conclusion, the symptomatic and asymptomatic thrombosis are common clinical entities in patients with gastric cancer. Metastatic stage and first 6 months after cancer diagnosis are the crucial periods in which the thrombosis mostly occurs. Although symptomatic thrombosis in patients with metastatic gastric cancer had an adverse prognostic effect, asymptomatic VTE had no significant impact on the prognosis, hence asypmtomatic VTE may be followed without anticoagulant therapy. However, more prospective randomize studies with large sample size investigating asymptomatic thrombosis are required in order to assess its prognostic significance and the need of treatment.

\section{REFERENCES}

1. Heit JA, Silverstein MD, Mohr DN, et al. Risk factors for deep vein thrombosis and pulmonary embolism: a population based case-control study. Arch Intern 160: 809-815, 2000.

2. Blom JW, Doggen CJ, Osanto S, et al. Malignancies, prothrombotic mutations, and the risk of venous thrombosis. JAMA 293: 715-722, 2005.
3. Furie B, Furie BC. Mechanisms of thrombus formation. N Engl J Med 359: 938-949, 2008.

4. Prandoni P, Falanga A, Piccioli A. Cancer and venous thromboembolism. Lancet Oncol 6: 401-410, 2005.

5. Varki A. Trousseau's syndrome: multiple definitions and multiple mechanisms. Blood. 110: 1723-1729, 2007.

6. Khorana AA, Liebman HA, White RH, et al. The Risk of Venous Thromboembolism in Patients with Cancer. Alexandria, VA: American Society of Clinical Oncology; ASCO Educational Book, 2008: 240-248.

7. Bennett CL, Silver SM, Djulbegovic B, et al. Venous thromboembolism and mortality associated with recombinant erythropoietin and darbepoetin administration for the treatment of cancer-associated anemia. JAMA 299: 914-924, 2008.

8. Falanga A, Lee AY, Streiff MB. Cancer and Thrombosis 3: Anticoagulation in the Treatment of Venous Thromboembolism in Patients with Cancer. ASCO Education Book, 2008: 258-268.

9. Francis CW, Kakkar AK, Levine MN. Prevention of Venous Thromboembolism in Patients with Cancer, ASCO Educational Book, 2008: 250-256.

10. Thodiyil PA, Kakkar AK. Variation in relative risk of venous thromboembolism in different cancers. Thromb Haemost 87: 1076-1077, 2002.

11. Levitan N, Dowlati A, Remick SC, et al. Rates of initial and recurrent thromboembolic disease among patients with malignancy versus those without malignancy: Risk analysis using Medicare claims data. Medicine (Baltimore) 78: 285-291, 1999.

12. Chew HK, Wun T, Harvey D, et al. The incidence of venous thromboembolism and its effect on survival among patients with common cancers. Arch Intern Med 166: 458-64, 2006.

13. Tetzlaff ED, Correa AM, Baker J, et al. The impact on survival of thromboembolic phenomena occurring before and during protocol chemotherapy in patients with advanced gastroesophageal adenocarcinoma. Cancer 109: 1989-1995, 2007.

14. Lee KW, Bang SM, Kim S, et al. The incidence, risk factors and prognostic implications of venous thromboembolism in patients with gastric cancer. J Thromb Haemost 8: 540-547, 2010.

15. Kang MJ, Ryoo BY, Ryu MH, et al. Venous thromboembolism in patients with advanced gastric cancer: an Asian experience. Eur J Cancer 48: 492-500, 2012.

16. Starling N, Rao S, Cunningham D, et al. Thromboembolism inpatients with advanced gastroesophageal cancer treated with anthracycline, platinum, and fluoropyrimidine combination chemotherapy: a report from the UK National Cancer Research Institute Upper Gastrointestinal Clinical StudiesGroup. J Clin Oncol 27: 3786-3793, 2009.

17. Tug E, Aydin H, Kaplan E, et al. Frequency of genetic mutations associated with thromboembolism in the Western Black Sea region. Intern Med 50: 17-21, 2011. 
18. Segers K, Dahlback B, Nicolaes GA. Coagultion factor V and thrombophilia: background and mechanisms. Thromb Haemost 98: 530-542, 2007.

19. Heath OM, van Beekhuizen HJ, Nama V, et al. Venous thromboembolism at time of diagnosis of ovarian cancer: Survival differs in symptomatic and asymptomatic cases. Throm Res 137: 30-35, 2016.

20. Gollin G, Ward B, Meier GH, et al. Central splanchnic venous thrombosis. Often unsuspected, usually uncomplicated. J Clin Gastroenterol 18: 109-113,1994.

21. Madonna P, De Stefano V, Coppola A, et al. G20210A prothrombin gene mutation and other trombophilic polymorphisms in patients with portal or hepatic venous thrombosis. Gastroenterology 120: 1059-1060, 2001.

22. Amitrano L, Brancaccio V, Guardascione MA, et al. High prevalence of thrombophilic genotypes in patients with acutemesenteric vein thrombosis. Am J Gastroenterol 96: 146-149, 2011.

23. Primignani M, Martinelli I, Bucciarelli $\mathrm{P}$, et al. Risk factors for thrombophilia in extrahepatic portal vein obstruction. Hepatology 41: 603-608, 2005.

24. Cronin CG, Lohan DG, Keane M, et al. Prevalence and significance of asymptomatic venous thromboembolic disease found on oncologic staging CT. AJR Am J Roentgenol 189: 162-170, 2007.

25. Singh R, Sousou T, Mohile S, et al. High rate of symptomatic and incidental thromboembolic events in gastrointestinal cancer patients. J Thromb Haemost 8: 1879-1881, 2010.

26. Lee AY, Levine MN, Baker Rl, et al. Low-molecular-weight heparin versus a coumarin for the prevention of recurrent venous thromboembolism in patients with cancer. N Engl $\mathrm{J}$ Med 349:146-153, 2003.

27. Hull RD, Pineo GF, Brant RF, et al. Long-term low-molecularweight heparin and warfarin for the secondary prevention of venous thromboembolism in patients with cancer. Am J Med 119: 1062-1072, 2006.
28. Ajani JA, Moiseyenko VM, Tjulandin S, et al. Clinical benefit with docetaxel plus fluorouracil and cisplatin compared with cisplatin and fluorouracil in a Phase III trial of advanced gastric or gastroesophageal cancer adenocarcinoma: the V-325 Study Group. J Clin Oncol 25: 3205-3209, 2007.

29. Bang YJ, Van Cutsem E, Feyereislova A, et al. Trastuzumab in combination with chemotherapy versus chemotherapy alone for treatment of HER2-positive advanced gastric or gastrooesophageal junction cancer (ToGA): a Phase 3, open-label, randomised controlled trial. Lancet 376: 687-697, 2010.

30. Chaturvedi S, Sidana S, Elson P, et al. Symptomatic and incidental venous thromboembolic disease are both associated with mortality in patients with prostate cancer. PLoS One 9: e94048, 2014.

31. Menapace LA, Peterson DR, Berry A, et al. Symptomatic and incidental thromboembolism are both associated with mortality in pancreatic cancer. Thromb Haemost 106: 371-378, 2011

32. Khorana AA. Cancer and thrombosis: implications of published guidelines for clinical practice. Ann Oncol 20: 16191630, 2009.

\section{Correspondence:}

Dr. Yakup BOZKAYA

Ankara Numune Egitim ve Arastirma Hastanesi

Tibbi Onkoloji Bölümü

06100, ANKAR / TURKEY

Tel: (+90-312) 5084601

Fax: (+90-312) 5084914

e-mail: dr_yakupbozkaya@hotmail.com 